Case Report

\title{
Transmission Expansion Planning for the Optimization of Renewable Energy Integration in the Sulawesi Electricity System
}

\author{
Tumiran ${ }^{1, *}$, Lesnanto Multa Putranto ${ }^{1}\left(\mathbb{D}\right.$, Roni Irnawan ${ }^{1}$, Sarjiya ${ }^{1}$, Adi Priyanto ${ }^{2}$, Suroso Isnandar ${ }^{2}$ and \\ Ira Savitri ${ }^{2}$ \\ 1 Department of Electrical and Information Engineering, Universitas Gadjah Mada, Grafika Street No. 2, \\ Yogyakarta 55281, Indonesia; Lesnanto@ugm.ac.id (L.M.P.); roniirnawan@ugm.ac.id (R.I.); \\ sarjiya@ugm.ac.id (S.) \\ 2 PT PLN (Persero), Trunojoyo Street, Blok M-I No.135, South Jakarta, DKI Jakarta 12160, Indonesia; \\ adi.priyanto@pln.co.id (A.P.); suroso.isnandar@pln.co.id (S.I.); ira.savitri@pln.co.id (I.S.) \\ * Correspondence: Tumiran@ugm.ac.id
}

check for updates

Citation: Tumiran; Putranto, L.M.; Irnawan, R.; Sarjiya; Priyanto, A.; Isnandar, S.; Savitri, I. Transmission Expansion Planning for the Optimization of Renewable Energy Integration in the Sulawesi Electricity System. Sustainability 2021, 13, 10477. https://doi.org/10.3390/ su131810477

Academic Editor: Ayman Attya

Received: 24 May 2021

Accepted: 9 September 2021

Published: 21 September 2021

Publisher's Note: MDPI stays neutral with regard to jurisdictional claims in published maps and institutional affiliations.

Copyright: (c) 2021 by the authors. Licensee MDPI, Basel, Switzerland. This article is an open access article distributed under the terms and conditions of the Creative Commons Attribution (CC BY) license (https:/ / creativecommons.org/licenses/by/ $4.0 /)$.
Abstract: In order to meet the growth in demand and the renewable energy integration target, the Sulawesi Electricity System (SES) should be expanded. Currently, the SES is divided into two systems, namely South and North Sulawesi. These two systems have different characteristics, such as the system size, reliability and operational cost. North Sulawesi is smaller, weaker and more expensive than the South System. In order to improve the system reliability, generation and transmission expansion planning should be executed simultaneously to meet the economical investment cost and satisfy the reliability standard. For this purpose, the necessity of a backbone system with a higher voltage level than the existing $150 \mathrm{kV}$ system should be considered, including the interconnection option between the two existing systems in Sulawesi. A methodology based on economic and technical criteria was developed to determine the backbone voltage level. Two voltage level options were considered, namely 275 and $500 \mathrm{kV}$. Several criteria were considered in order to determine the backbone voltage level, including the economic voltage, the line-loading limit, N-1 contingency, short circuiting, transient stability, voltage stability and small signal stability. The backbone voltage candidates should fulfil all of the criteria. The simulation was conducted in base- and high-demand scenarios, considering the fluctuation of future economic growth. The load flow and the dynamic analysis were simulated in a DIgSILENT Power Factory environment. The results showed that the $275 \mathrm{kV}$ backbone, which was built in 2022, would violate three criteria: the economic voltage, N-1 contingency and voltage stability. On the other hand, the $500 \mathrm{kV}$ backbone voltage level fulfills all of the criteria. The result of this research was considered in the electricity planning documents in Sulawesi. From a technical and economical perspective, the $500 \mathrm{kV}$ backbone was chosen for the SES.

Keywords: transmission expansion planning; backbone voltage level; economic voltage; N-1 contingency; voltage stability

\section{Introduction}

Indonesia is the fourth largest country in the world, with almost 268 million residents in 2018 [1]. This population is expected to grow at a rate of $1.1 \%$, which is the same as the world's population growth rate [2]. Although there are at least 17,000 islands in Indonesia, around $85 \%$ of the population are living on three islands: Java (56\%), Sumatra (21\%) and Sulawesi (7\%), as shown in Figure 1 [3]. The development of infrastructure, which supports business growth, is focused mostly on Java, where the government and business capitals are based. 


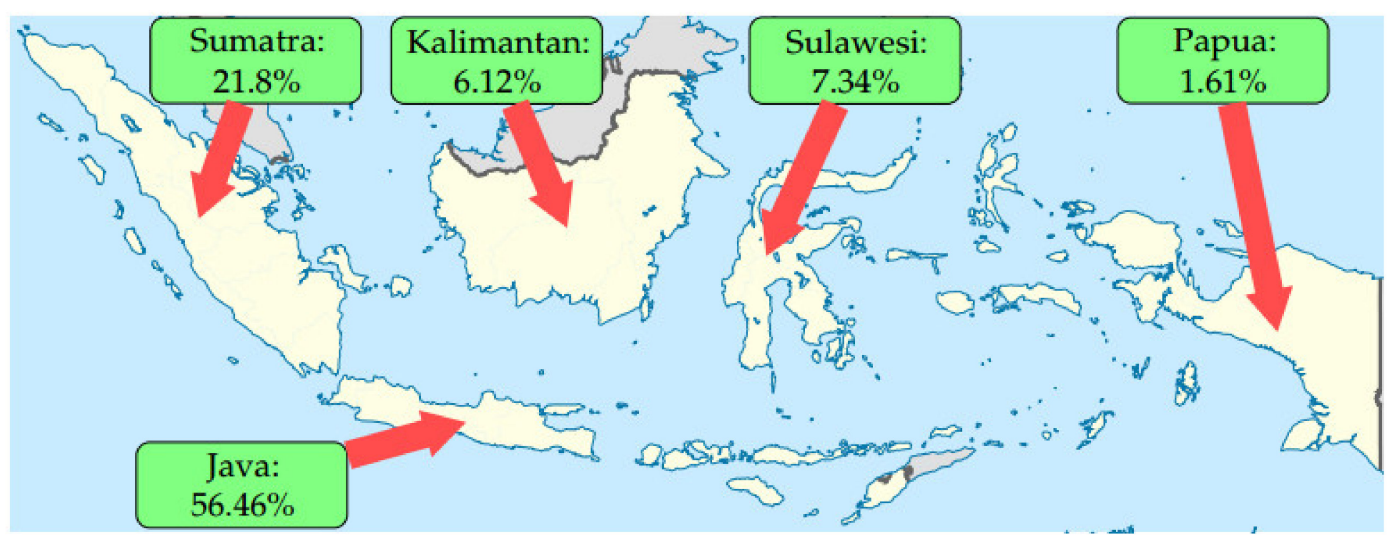

Figure 1. Map of the population distribution in indonesia [3].

Access to electricity and its reliability are among the decisive factors for investors to establish a new business [4]. Currently, not all of the residents of Indonesia have access to electricity, especially outside Java. It is only in Java that the electrification rate, which represents the number of households that have been provided with some form of electricity supply divided by the total number of households, reaches 100\% [5]. However, outside Java, the electrification rate reaches up to $90.54 \%$ [5]. In terms of the system average interruption duration index (SAIDI) and the system average interruption frequency index (SAIFI), each costumer in Java has an SAIDI of $9.46 \mathrm{~h}$ and an SAIFI of 6.27 interruptions, whereas outside Java, the SAIDI number reaches $26.36 \mathrm{~h}$ /costumer and 15.7 interruptions/costumer [5].

As one of the world's emerging markets, Indonesia has the highest Gross Domestic Product (GDP) among the members of the Association of Southeast Asian Nations (ASEAN), i.e., the 16th largest nominal GDP in the world, or the seventh largest in the world if based on Purchasing Power Parity (PPP) [6]. In addition to the fact that its industries are mainly located in Java, in 2018, most of the electricity in Indonesia was sold to residential customers $(41.7 \%$ or $97,832.28 \mathrm{GWh})$, while only $32.8 \%$ - or $76,946.50 \mathrm{GWh}$ was sold to industries [5]. Hence, Indonesia's energy per capita is among the lowest in the ASEAN. In 2014, a total of $811 \mathrm{kWh}$ /capita was consumed in Indonesia, while Singapore's electricity consumption was 10 times larger than this or Malaysia, which is 5 times larger [7].

In order to accelerate the industrial development to the entire territory of Indonesia, ten Industrial Development Areas were established in 2015 [8]. Seven of them are in the eastern part of Indonesia (i.e., Kalimantan, Sulawesi, Papua, Bali and Nusa Tenggara), two are in Sumatra and one area is in Java. Furthermore, 14 industrial estates have also been developed in these areas outside Java. They occupy a total of 28,854 hectares, and $40 \%$ of these are located in Sulawesi [9].

Sulawesi is expected to become the center for stainless steel-based industries [8]. At least three large smelters to purify nickel are currently being built (becoming part of the 14 industrial estates), i.e., Morowali, Konawe and Bantaeng. With these three estates, it is expected that Indonesia will be able to export more than 6 million tons of stainless steel per year [9]. Furthermore, Sulawesi also plays an important role as the hub between the eastern part of Indonesia and the rest of the world. Therefore, developing the infrastructure in Sulawesi is necessary in order to enhance the contribution of the eastern part of Indonesia to the national GDP $[8,9]$.

These industrial estates are expected to attract new workers from different parts of Indonesia, i.e., they demobilize the people from going to Java. Hence, apart from supplying the industrial estates, the electricity is also required to supply residents. In the last 7 years, the electric energy sales in Sulawesi increased at a rate of 9\%, i.e., from 5.6 TWh in 2011 to 9.9 TWh in 2018 [10]. Based on this number, it is expected that the electrical energy sales will reach 23 TWh in 2028. The realization and estimation of the electrical energy sales in Sulawesi are shown in Figure 2. 


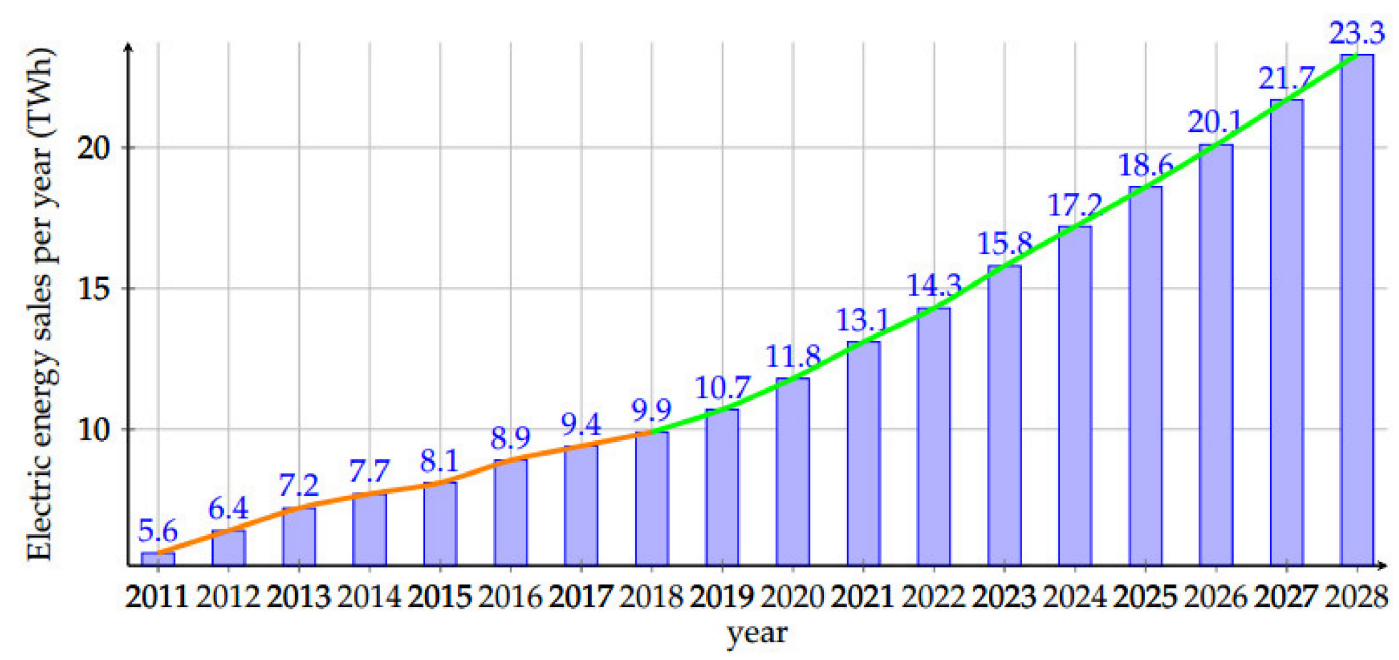

Figure 2. Expected electric energy sales [10].

In order to meet the demand, both the generation and transmission systems need to be expanded. Currently, renewable energy resources are important in expansion planning, not only to generate green energy but also to maximize the local natural resources. Various studies have been conducted regarding the integration of renewable energy into generation expansion planning. Solar, wind and biomass energy are some examples of the renewable energy that is integrated in the Brazilian, European and German systems [11-13]. However, the integration of renewable energy can cause uncertainty, such as fluctuation, as most of the renewable energy has an intermittent nature. Therefore, in [12,14], this problem is discussed in order to provide better results in generation expansion planning.

Furthermore, the transmission line can also be used to maximize the deliverability of potential renewable energy. In [13], the development of renewable integration in Europe is discussed from a transmission network perspective. However, the integration of renewable energy resources is not only limited in the transmission network but can also be integrated into the distribution network. In [15], the integration of renewable energy into the distribution network is discussed.

In the period of 2019-2028, it is expected that the installed capacity of the generating units in Sulawesi will increase by $5423 \mathrm{MW}$ (or $542 \mathrm{MW}$ per year) [10]. These new generating units are hydro/mini-hydro (34.9\%), coal (34.7\%), gas $(26.1 \%)$, solar and wind $(2.6 \%)$, and others $(1.7 \%)$. This composition met the renewable energy mix target of $23 \%$ by 2025 [16]. This generation expansion planning follows a resource-based approach, which means that the generating unit is installed near to its primary source [10]. This means that the electricity needs to be transmitted to the load centers using a transmission system. The option to build a new power plant near the load center might not be taken, due to, for example, land availability and the distribution chain of the raw energy (such as coal) to this power plant location.

In Sulawesi, currently, there are two systems: Northern Sulawesi and Southern Sulawesi [10]. The existing transmission systems are presented in Figure 3, and consist of 150 and $275 \mathrm{kV}$ lines. The Southern System is bigger than the Northern System; the peak loads are 1413 and $421 \mathrm{MW}$, and the current generation capacities are 1977 and $573 \mathrm{MW}$ [17,18]. On the other hand, the electricity growth is also high, and the location of the green energy resources is far away. For this reason, the government planned to connect these two systems, allowing the transmission of green natural energy resources on this island. With the interconnection of the system, the system reliability will increase. In addition, the levelized cost of electricity (LCOE) will become cheaper due to the sharing of energy between the interconnected systems. 


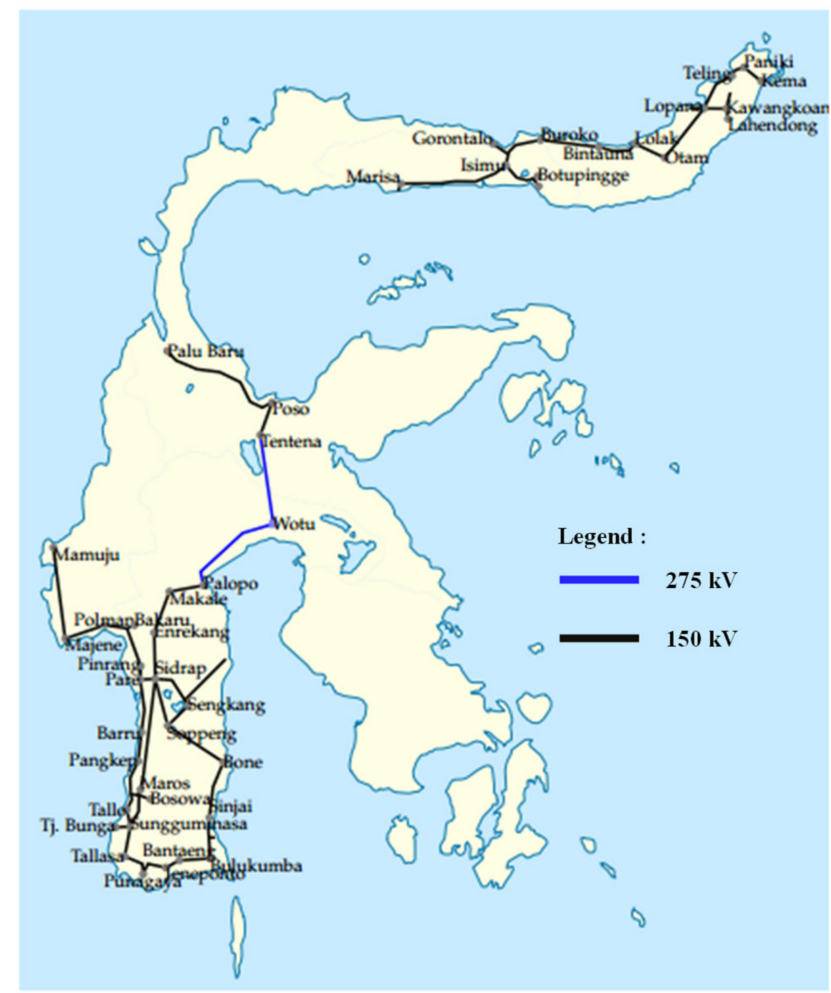

Figure 3. Existing transmission line in the Sulawesi system.

To interconnect the two systems using a backbone transmission system, a transmission expansion planning procedure is necessary. The procedure is carried out in order to develop or improve the ability of the transmission system so that it can meet the demand for electrical energy and optimize the power plant's utilization $[19,20]$. In the planning procedure, it is necessary to identify when and where a new transmission line will be built. This also depends on the capacity and voltage level of the transmission system, which is influenced by several factors, such as the electricity demand, the location of the power plants, and the reliability target of the electrical system [21]. Various studies related to transmission planning have been carried out $[19,20,22-29]$. From the previous research, the reliability of the transmission system is important to consider in transmission planning. The N-1 contingency reliability criteria must be considered in transmission planning to ensure that energy is delivered to the costumer $[23,28]$. Moreover, the procedure would minimize the generation cost while providing sustainable and affordable energy, such that the increasing growth of the electricity system encourages economic growth in the region [20]; take, for example, the project conducted in [24], which conducts research related to the inter-regional power grid in China.

A methodology based on economic and technical criteria was developed to determine the backbone voltage level, by considering several criteria of the transmission line. This paper also shows different development scenarios based on the load projections and generator expansion planning in Sulawesi. Furthermore, several criteria to quantify the choice of the voltage level were used to evaluate the choice of the voltage level. As a result, the backbone voltage level would be $500 \mathrm{kV}$, which would initially be installed in 2021 . The existing 150 and $275 \mathrm{kV}$ system would no longer be sufficient to transmit the power. With this design, the Sulawesi electricity system will be more reliable, economical and environmentally friendly. The result of this study was considered in electrical planning documents in Indonesia [10], especially for the transmission line development design in Sulawesi for the next 30 years. 


\section{Primary Energy Resources and Load Demand}

Sulawesi Island has abundant primary energy resources, both non-renewable—such as coal and natural gas - and renewable, such as geothermal, hydro, solar, wind and biomass. The amount of primary energy potential in Sulawesi Island is presented in Table 1 . The non-renewable primary energy sources of coal and natural gas have potentials of 2049 and $795 \mathrm{MW}$, respectively. Meanwhile, renewable energy sources, including geothermal, wind, hydro, solar and biomass, have potentials of $1148 \mathrm{MWe}, 4105,5174,27,821$ and $2086 \mathrm{MW}$, respectively [18].

Table 1. Primary energy resource potential.

\begin{tabular}{cc}
\hline Energy Resources & Amount of Potential \\
\hline Coal & $2049 \mathrm{MW}$ \\
\hline Natural Gas & $795 \mathrm{MW}$ \\
\hline Geothermal & $1148 \mathrm{MWe}$ \\
\hline Wind & $4105 \mathrm{MW}$ \\
\hline Hydro & $5174 \mathrm{MW}$ \\
\hline Solar & $27,821 \mathrm{GW}$ \\
\hline Biomass & $2086 \mathrm{MW}$ \\
\hline
\end{tabular}

These primary energy resources can generate electricity in order to meet the demand. Considering the renewable energy source (RES) mixed target, an RES generating unit should be installed in the system. Hydro and wind energy are the most suitable options due to the potential and matureness of the technology. Solar generation was not chosen due to its high capital cost and the land use issue. However, the long distance between the load centers and resources is an issue, as shown in Figure 4. For example, the load center is located in Makassar City, while the hydro energy resources are located around Pinrang District, which is $240 \mathrm{~km}$ away, and the wind energy resources are located in Sidrap, which is $175 \mathrm{~km}$ away.

Therefore, it is necessary to build an interconnection system connecting Northern Sulawesi and Southern Sulawesi to deliver RES generation to the load center. Furthermore, the RES location is far from the load center. Another consideration for interconnection is that the total cost of the system would be more economical and reliable than isolated systems. These interconnection and generation costs are also considered into the expansion planning process. Hence, transmission expansion planning is needed to maximize the deliverability of the RES generation. 


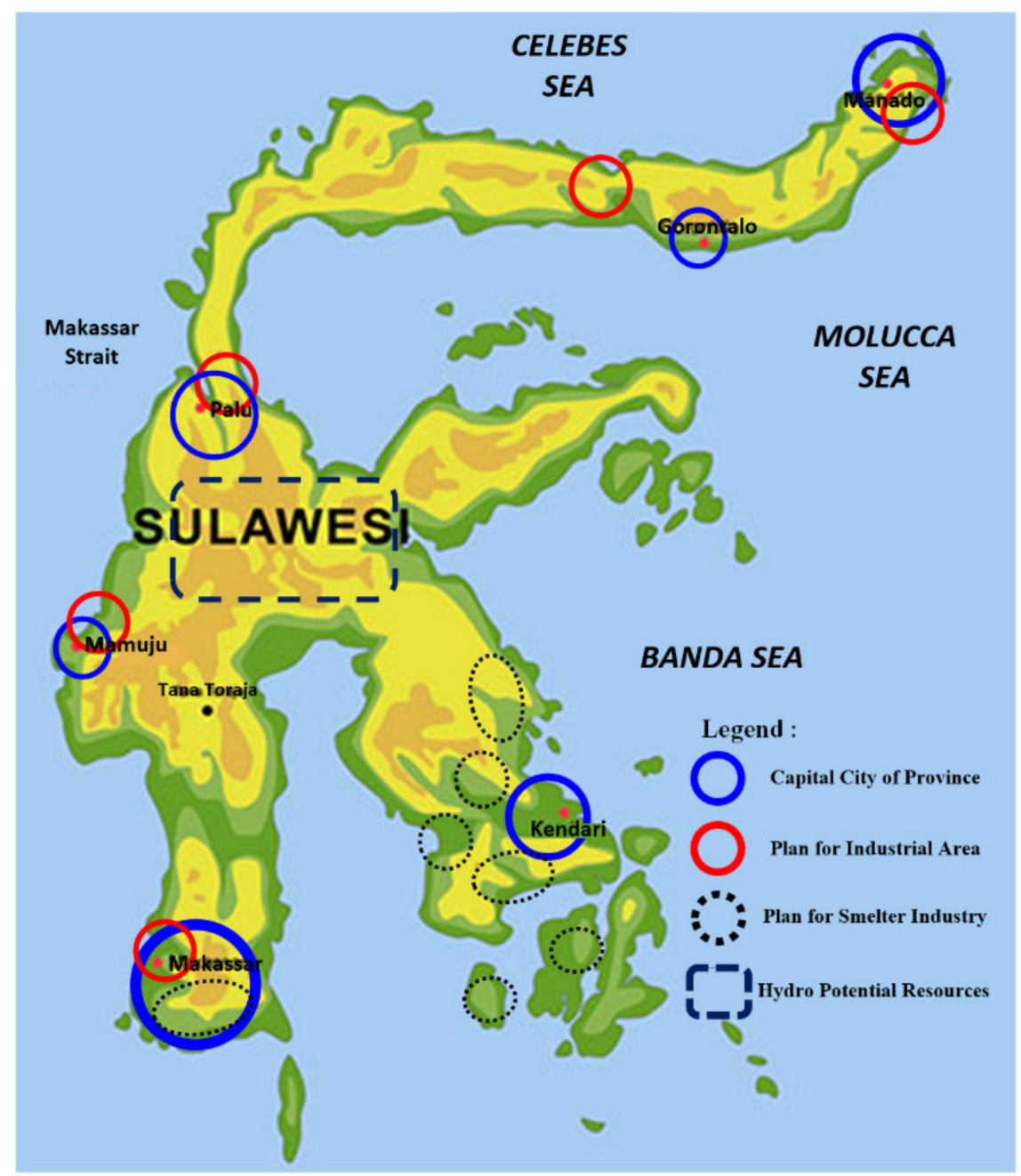

Figure 4. Map of the load center and potential hydro resources in Sulawesi.

\section{Transmission Expansion Planning Methodology}

The transmission voltage level is the critical issue to be decided. At the time, there were two options to choose from, 275 and $500 \mathrm{kV}$. The selection of the voltage levels on the transmission line considers various criteria, including load growth factors, capital investment costs, land acquisition costs, power flow analysis, short circuiting, stability dynamics and reliability, as presented in Figure 5. Seven criteria were considered in the determination from the technical aspects, namely the economic voltage, voltage angle, contingency $\mathrm{N}-1$, short circuiting, transient stability, voltage stability and small signal stability, which were evaluated in every time slice. Considering only the economic perspective, low-level voltage would be chosen as the solution due to the low investment cost. On the other hand, the high-level voltage has better technical requirements than the low-level voltage. In order to address these concerns, the procedure was simulated for these two voltage levels, starting from the low-level voltage. If the low-level voltage satisfied the technical and economic procedures, the simulation could be stopped. 


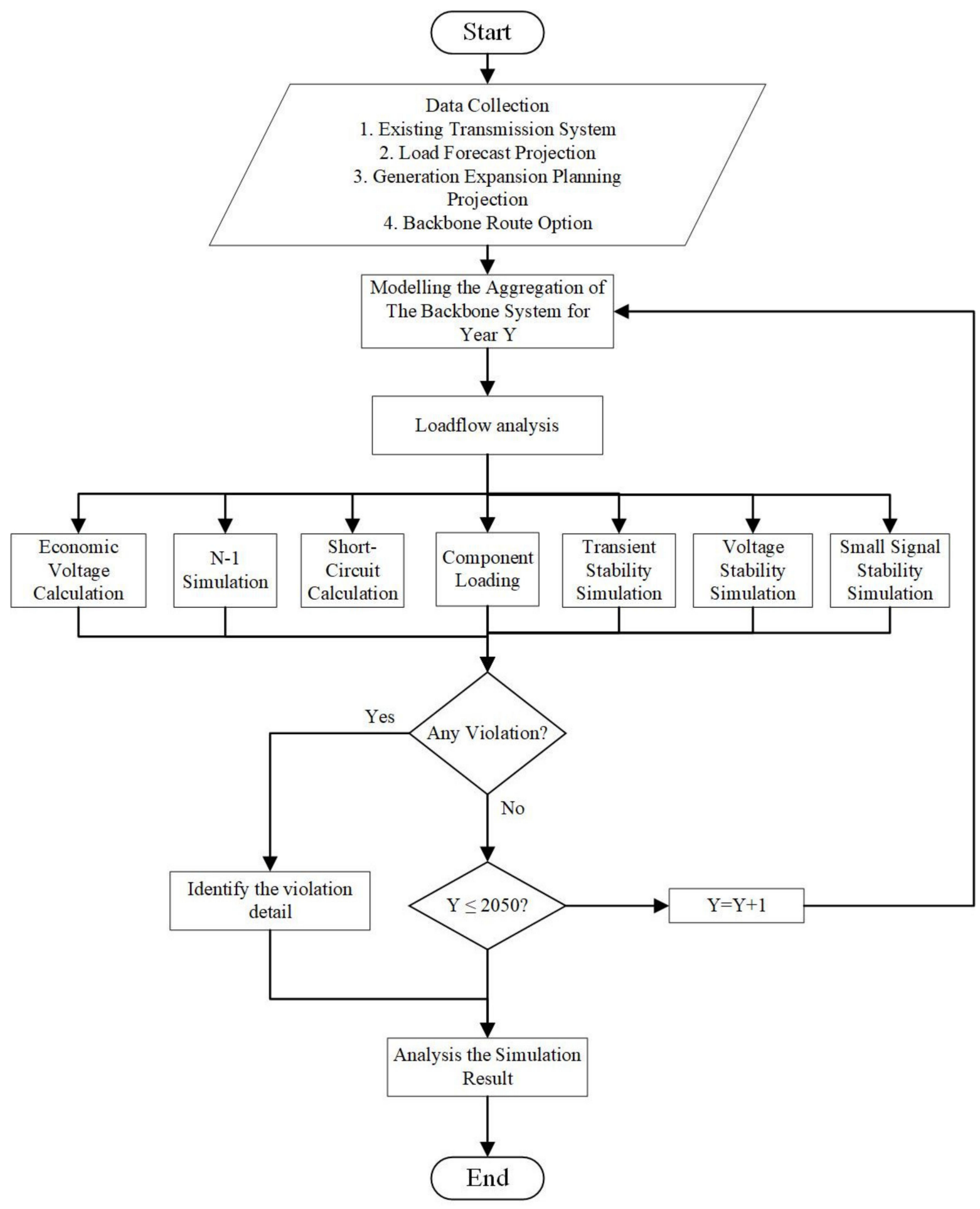

Figure 5. Methodology of the transmission voltage determination.

The details of several criteria used in the simulation procedure are presented in the following.

\subsection{Economic Voltage}

The economic voltage is the voltage level when the total cost of the conductors, transformers, switchgear, insulators and other equipment is at a minimum. The relationship between the capital cost and the transmission voltage level is shown in Figure 6. Point $\mathrm{Z}$ is the minimum point, and the voltage at $\mathrm{OX}$ is the optimum transmission voltage [30]. 


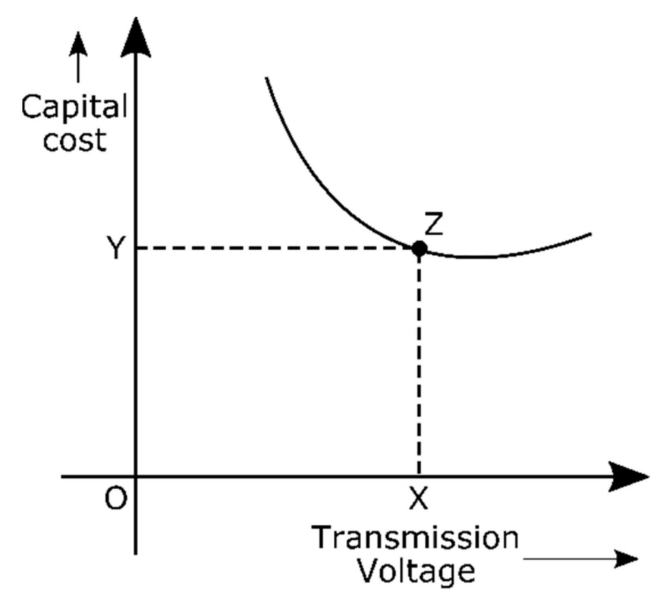

Figure 6. Economic voltage of the transmission line.

However, the method of locating the economical transmission line voltages, as described above, is rarely used due to difficulties in determining the initial cost of the equipment associated with the transmission line. Therefore, it is calculated using an empirical formula to determine the economical transmission line voltage for the three-phase AC power system. The equation is formulated in Equation (1). Based on this equation, the economical transmission line voltage $(\mathrm{V}$ in $\mathrm{kV})$ depends on the length of the transmission line $(\mathrm{L}$ in $\mathrm{km})$ and the power transferred by the transmission line (P in $\mathrm{kW})$ [30].

$$
\mathrm{V}=5.5 \sqrt{0.62 \mathrm{~L}+\frac{\mathrm{P}}{150}}
$$

\subsection{Voltage Profile and Loading}

The voltage angle in the phasor diagram shows the sine wave phase of the corresponding voltage. When electric power is transferred through the transmission line, there is a difference in the voltage angles at the two ends of the transmission line; this is due to the impedance in the conducting wire. In the transmission line planning evaluation, the difference in the voltage angle between the two ends of the transmission line must not exceed $30^{\circ}$. The allowable values of the line loading and voltage profile in the normal condition and $\mathrm{N}-1$ condition are shown in Table 2 . The voltage angle value can be obtained from the load flow results; then, the voltage angle difference can be calculated for each transmission line. Besides the voltage angle, the results of the load flow also show the voltage magnitude, active power and reactive power. The allowable voltage magnitude limit is $\pm 5 \%$, while the maximum power flow limit is $80 \%$ [31-33]. In the transmission line planning, it should be noted that when an N-1 contingency occurs, the system should withstand it to supply power to the load. The voltage magnitude limit when an N-1 contingency occurs is $\pm 5 \%$, while the power flow limit is $100 \%$.

Table 2. Allowable value of the voltage profile and line loading.

\begin{tabular}{ccc}
\hline \multirow{2}{*}{ Criteria } & \multicolumn{2}{c}{ Allowable Value } \\
\cline { 2 - 3 } & Normal Condition & N-1 Condition \\
\hline Power Flow Loading & $80 \%$ & $100 \%$ \\
\hline Voltage Magnitude & & \\
\hline Voltage Angle & $\pm 5 \%$ & \\
\hline
\end{tabular}

\subsection{Short Circuit}

Short circuiting on the transmission line can be caused by various factors, which result in an uncontrolled flow of current and can cause equipment damage. There are two 
types of short circuits, namely symmetrical short circuits caused by three-phase faults, and asymmetric short circuits caused by a line to line fault, single line to ground or double line to ground. Transmission lines with different voltage levels have different short-circuit currents, so it should be noted that the short-circuit current must not exceed the limits shown in Table 3.

Table 3. Allowable short circuit current for each voltage level.

\begin{tabular}{cc}
\hline Voltage Class & Allowable Short Circuit Current \\
\hline $70 \mathrm{kV}$ & $20 \mathrm{kA}$ or less \\
\hline $150 \mathrm{kV}$ & $30 \mathrm{kA}$ or less \\
\hline $275 \mathrm{kV}, 500 \mathrm{kV}$ & $40 \mathrm{kA}$ or less \\
\hline
\end{tabular}

\subsection{Transient Stability}

A transient event is a change in states that occurs suddenly; in electric power transmission, a transient event can be caused by a fault, such as a short circuit. It is necessary to evaluate whether, when a transient event occurs, the system can return to a stable condition or not. The generator is the component most affected when a transient event occurs, especially in the balance of mechanical power and electrical power, which will affect the angle of the rotor $(\delta)$. When a fault occurs, $\delta$ will increase; if $\delta$ continues to increase, it will result in a loss of synchronism; it is, therefore, necessary to conduct interference before $\delta$ reaches the critical point, called the critical clearing angle $\left(\delta_{C}\right)$ [33].

The critical clearing time (CCT) is the time needed from the occurrence of the fault until it reaches the critical clearing angle $\left(\delta_{C}\right)$. Interference must be conducted before the $\mathrm{CCT}$ time is exceeded; the greater the $\mathrm{CCT}$, the better, as there is more time for interference. The minimum CCT limits for each voltage level are shown in Table 4 [33].

Table 4. Minimum critical clearing time requirement for each voltage level.

\begin{tabular}{cc}
\hline Voltage Level & Minimum CCT (ms) \\
\hline $150 \mathrm{kV}$ & 120 \\
\hline $275 \mathrm{kV}$ & 100 \\
\hline $500 \mathrm{kV}$ & 90 \\
\hline
\end{tabular}

\subsection{Voltage Stability}

The voltage stability on a bus/station depends on the amount of power transferred through the bus/station, and the relationship between the power transfer and the voltage, as shown in Figure 7. Figure 7 shows that the greater the power transfer, the smaller the voltage, up to the critical point $\left(\mathrm{P}_{\text {crit }}\right)$; if the power transfer exceeds $\mathrm{P}_{\text {crit, }}$, then voltage collapse will occur. Voltage collapse is a condition in which the power transfer reaches the limit that causes the system to collapse, as shown by a decrease in the power transfer coupled with a significant voltage drop. In order to avoid the voltage collapse, the operating point of the power transfer is limited to a maximum of $90 \%$ of the $\mathrm{P}_{\text {crit }}$ based on [33]. 


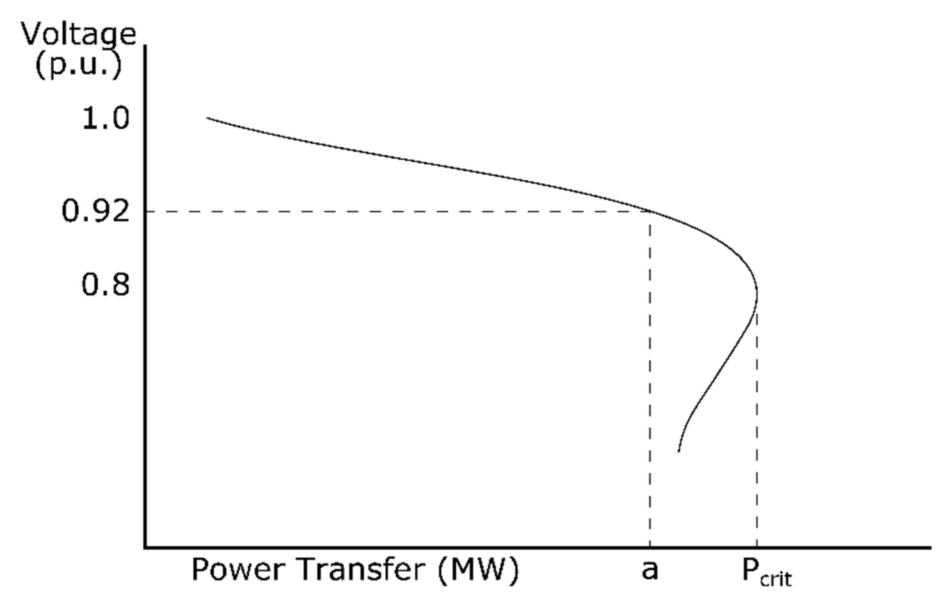

Figure 7. PV curve/nose curve for the voltage stability evaluation.

\subsection{Small Signal Stability}

Small signal stability is the stability of the system when faced with minor disturbances such as sudden load changes. When load changes occur, the generator must be able to respond by changing the power produced. In response to load changes, the generator is usually equipped with equipment such as a Load Frequency Control (LFC), an Automatic Voltage Regulator (AVR) and a Power System Stabilizer (PSS). In the small signal stability analysis, the generator is modeled as a block diagram. Based on the block diagram, state equations can be formulated in a general form, as shown in Equation (2) [33,34]. The variable $u$ in the equation is the input, which includes the excitation voltage, turbine power and torque input, while variable $x$ is the state variable, which includes the rotor current and rotor flux [35]. The linearized dynamic model of the Sulawesi system was modeled using the Equation (2). The system is stable if the eigenvalue of matrix $A$ is negative in its real component, as illustrated in Figure 8 [33].

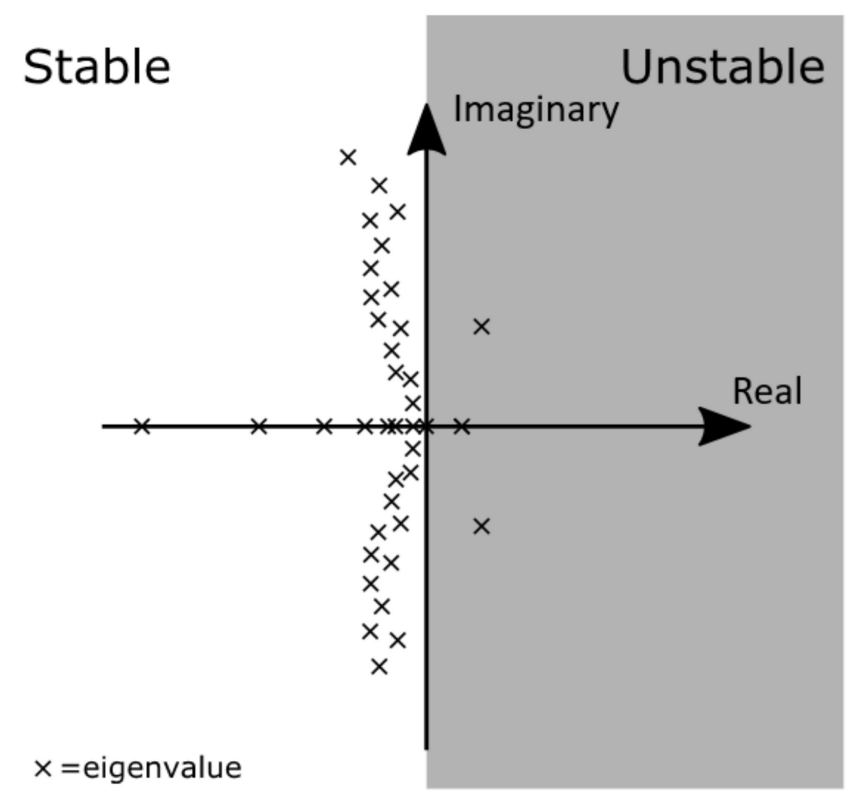

Figure 8. Illustration of a small signal stability area.

$$
\begin{aligned}
& \dot{x}(t)=A x(t)+B u(t) \\
& y(t)=C x(t)+D u(t)
\end{aligned}
$$

With:

$\mathrm{A}=$ the state matrix, 
$\mathrm{B}=$ the input matrix,

$\mathrm{C}=$ the output matrix,

$\mathrm{D}=$ the direct transmission matrix,

$\mathrm{x}(\mathrm{t})=$ a state variable,

$y(t)=$ an output variable,

$\mathrm{u}(\mathrm{t})=$ the input data.

\section{Initial Data and Assumption}

This study only discusses the transmission voltage levels, namely 275 and $500 \mathrm{kV}$. Therefore, transmission and distribution facilities that have voltage levels below these were modelled as a lump load (aggregated load).

Some initial data were required to execute the transmission expansion planning, which were the load forecast, the required generating unit for the whole-time horizon, and the transmission line routes.

\subsection{Load Forecast}

There are two scenarios in the load forecast, namely the base-demand scenario and the high-demand scenario. The base-demand scenario uses the business-as-usual concept, meaning that growth runs normally and there are no large increases in the load. Meanwhile, the high-demand scenario refers to high economic growth and a large increase in loads, especially from new industries, such as smelters, that consume a large amount of electrical energy.

The forecast results for the peak load of the SES are shown in Figure 9. The average peak load growths for the Sulawesi system were 5.53\% and 6.33\% annually for the basedemand scenario and the high-demand scenario, respectively. In the final year of the planning period of 2050, the peak load reached 14,597 MW for the base-demand scenario and 19,887 MW for the high-demand scenario.

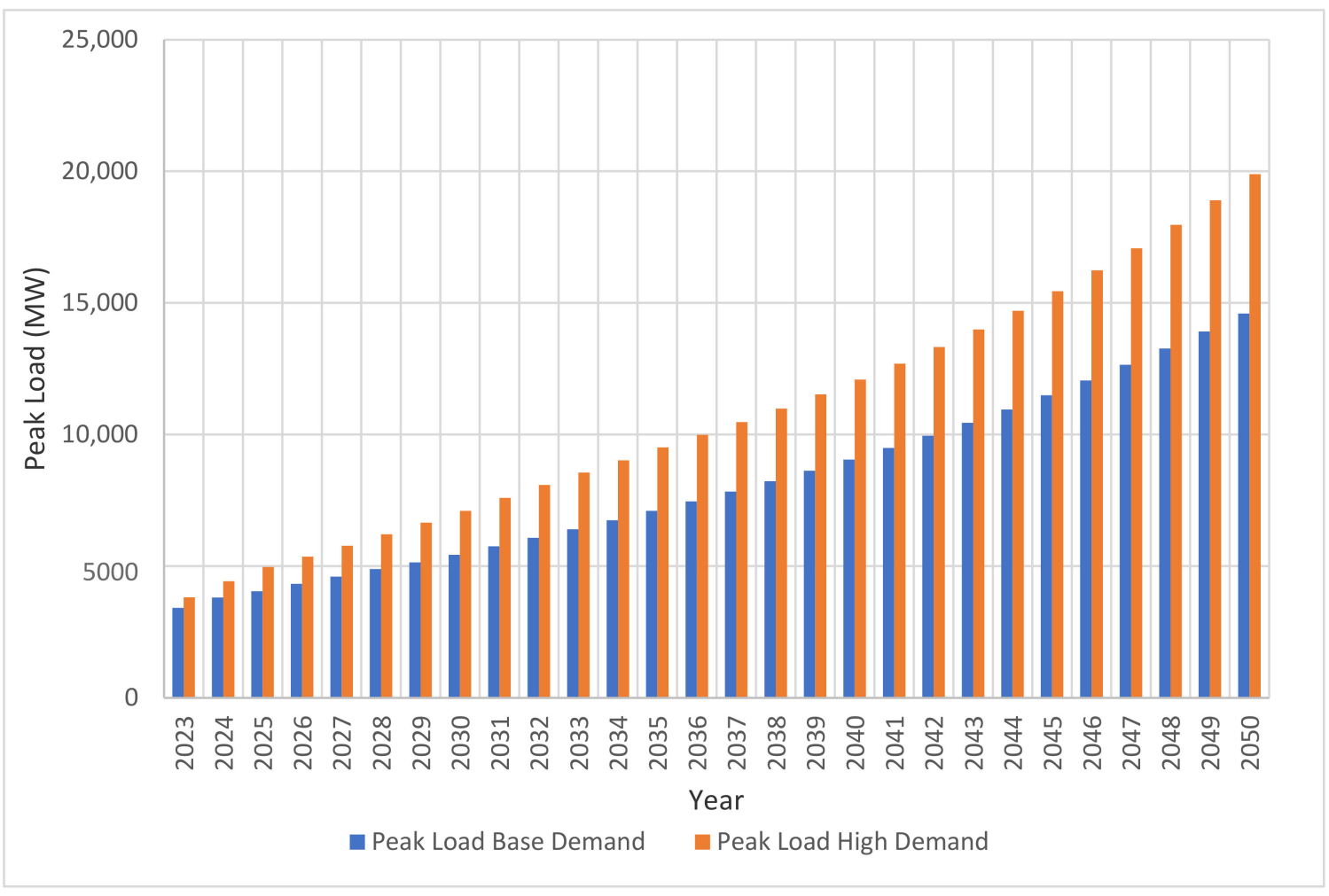

Figure 9. Demand forecast for the Sulawesi system [18]. 


\subsection{Generation Expansion Planning Result}

In generation expansion planning (GEP), there are several types of power plant candidates, namely steam turbines, gas turbines, combined cycles, geothermal and hydro. The choice of which plant to build and when to build is determined based on the least-cost optimization procedure. These costs consider capital, operation and maintenance, and fuel costs. The GEP data in 5-year intervals are shown in Table 5.

Table 5. Total capacity of each generating unit type in MW [18].

\begin{tabular}{|c|c|c|c|c|c|c|c|c|c|c|c|c|}
\hline \multirow[t]{2}{*}{ Year } & \multicolumn{6}{|c|}{ Base Demand (MW) } & \multicolumn{6}{|c|}{ High Demand (MW) } \\
\hline & Steam & Geothermal & Gas & $\begin{array}{c}\text { Combine } \\
\text { Cycle }\end{array}$ & Hydro & Wind & Steam & Geothermal & Gas & $\begin{array}{l}\text { Combine } \\
\text { Cycle }\end{array}$ & Hydro & Wind \\
\hline 2025 & 2316 & 131 & 1195 & 150 & 1926.1 & 130 & 3816 & 111 & 1395 & 150 & 1926.1 & 130 \\
\hline 2030 & 3516 & 132 & 1395 & 150 & 1968.1 & 190 & 5016 & 132 & 2595 & 450 & 1968.1 & 190 \\
\hline 2035 & 3816 & 99 & 2325 & 150 & 2928.1 & 190 & 6816 & 99 & 3125 & 600 & 2928.1 & 190 \\
\hline 2040 & 5016 & 80 & 2680 & 150 & 3923.1 & 190 & 8816 & 80 & 3280 & 600 & 3923.1 & 190 \\
\hline 2045 & 6631 & 40 & 3350 & 300 & 4953.1 & 190 & 11,631 & 40 & 3750 & 600 & 4953.1 & 190 \\
\hline 2050 & 10,000 & 40 & 3200 & 150 & 5534.1 & 190 & 15,000 & 40 & 5200 & 900 & 5534.1 & 190 \\
\hline
\end{tabular}

Based on Table 5, the capacity of hydro generating units for the base demand and the high demand is the same. This is due to the fact that the planning of hydro plants was carried out separately from thermal plants, and hydro plants were determined deterministically based on $[17,36]$. The compositions of the non-RE generating units (Steam, Gas and Combined Cycle) for the base-demand scenario for 2025, 2040 and 2050 were $62.6 \%, 65.17 \%$ and $69.84 \%$, respectively. Meanwhile, the compositions of the RE generating units were $37.4 \%, 34.83 \%$ and $30.16 \%$. For the high-demand scenario, the compositions of the non-RE generating units were $71.21 \%, 75.17 \%$ and $78.54 \%$ for 2025,2040 and 2050 , respectively. The compositions of the RE generating units for this scenario were $28.79 \%, 24.83 \%$ and $21.46 \%$ in 2025, 2040 and 2050.

\subsection{Backbone System Route}

The backbone line route was determined by considering the transmission, interconnection time and generation costs. The interconnection system will be built in 2025, as it took 7 years starting from 2018 for the planning, project auction, site and feasibility studies to the construction of the transmission system. The backbone route of the SES in the high-demand scenario is shown in Figure 10. In Figure 10, only the backbone line route is presented, while the existing $150 \mathrm{kV}$ transmission system is aggregated into the backbone. In addition, the year of construction and the length of the transmission line candidates can be seen in Table 6. 


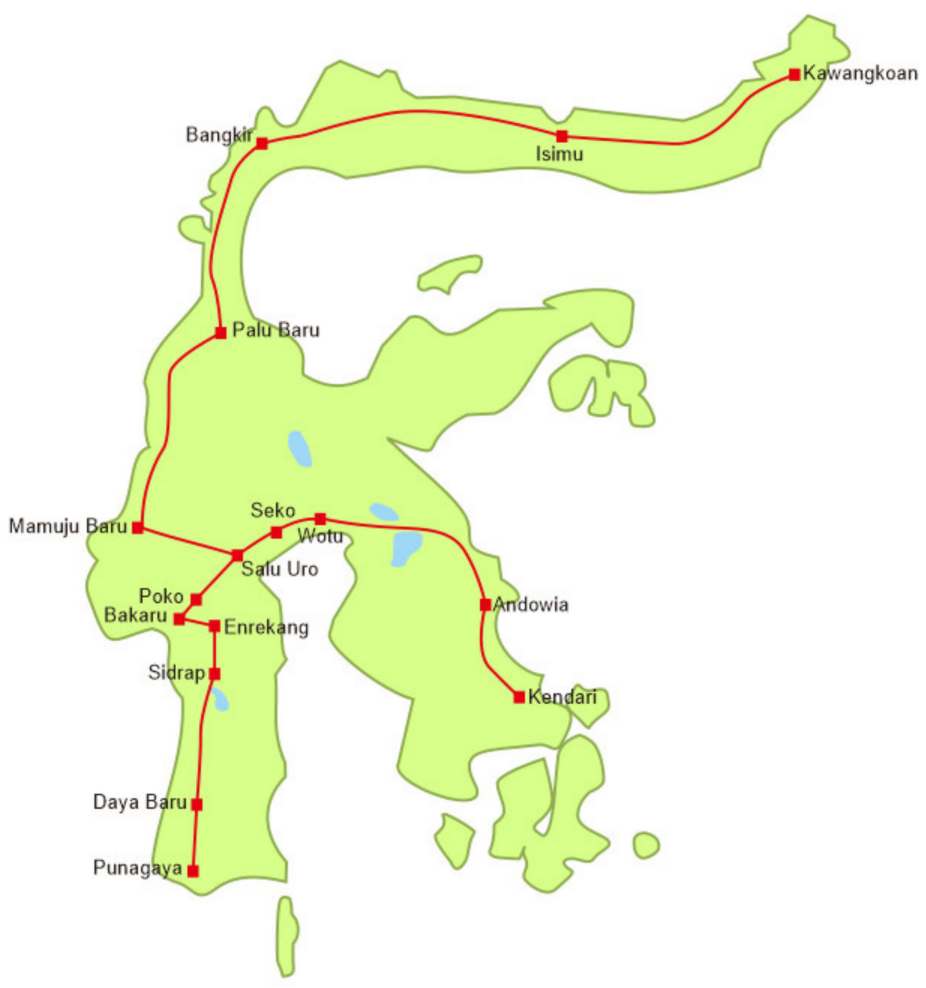

Figure 10. Route of the transmission line backbone for the Sulawesi system.

Table 6. Transmission line candidates for the Sulawesi system.

\begin{tabular}{ccc}
\hline Line & Length $\mathbf{( k m )}$ & Year \\
\hline Daya Baru-Sidrap & 175 & 2021 \\
\hline Punagaya-Daya Baru & 70 & 2021 \\
\hline Sidrap-Enrekang & 40 & 2022 \\
\hline Enrekang-Plta Bakaru 2 & 25 & 2022 \\
\hline PLTA Bakaru 2-PLTA Poko & 20 & 2022 \\
\hline PLTA Poko-PLTA Salu Uro & 120 & 2022 \\
\hline PLTA Salu Uro-Mamuju Baru & 55 & 2022 \\
\hline PLTA Salu Uro-PLTA Seko & 75 & 2023 \\
\hline PLTA Seko-Wotu & 75 & 2023 \\
\hline Mamuju Baru-Palu Baru & 255.5 & 2023 \\
\hline Wotu-Andowia & 260 & 2023 \\
\hline Andowia-Kendari & 67.5 & 2023 \\
\hline Palu Baru-Bangkir & 195 & 2026 \\
\hline Bangkir-Isimu & 429 & 2029 \\
\hline Isimu-Kawangkoan & 381.693 &
\end{tabular}

\section{Results and Discussion}

This section discusses the result of the backbone transmission line development plan in the SES until 2050. There are two options for the transmission voltage level: 275 and $500 \mathrm{kV}$ voltage level backbones. In the simulation, two load forecast and interconnection options were considered. 


\subsection{Criteria Evaluation}

Simulations to ensure the economical and technical criteria were executed in the DIgSILENT Power Factory software environment. This simulation aimed to determine whether there are criteria that are violated or not; based on the simulation, the results were obtained as shown in the Table 7.

Table 7. Criteria evaluation for the 275 and $500 \mathrm{kV}$ backbones.

\begin{tabular}{ccccc}
\hline \multirow{2}{*}{ Criteria } & Base & High & Base & High \\
\cline { 2 - 5 } & Safe & Safe & Safe & Safe \\
\hline $\begin{array}{c}\text { Loading } \\
\text { Magnitude }\end{array}$ & Safe & Safe & Safe & Safe \\
\hline Voltage Angle & Safe & Safe & Safe & Safe \\
\hline $\begin{array}{c}\text { Economic } \\
\text { Voltage }\end{array}$ & Safe & $\begin{array}{c}\text { Not Safe } \\
\text { (violated at 2029) }\end{array}$ & Safe & Safe \\
\hline $\begin{array}{c}\text { N-1 Contingency } \\
\text { Short Circuit }\end{array}$ & Safe & $\begin{array}{c}\text { Not Safe } \\
\text { (violated at 2034) }\end{array}$ & Safe & Safe \\
\hline $\begin{array}{c}\text { Transient } \\
\text { Stability }\end{array}$ & Safe & Safe & Safe & Safe \\
\hline $\begin{array}{c}\text { Voltage Stability } \\
\text { (violated at 2037) }\end{array}$ & Safe & Safe & Safe & Safe \\
\hline $\begin{array}{c}\text { Small Signal } \\
\text { Stability }\end{array}$ & Safe & Not Safe & Safe & Safe \\
\hline
\end{tabular}

Based on the load flow analysis, the economic voltage can be calculated for each transmission line using the line-length data and the amount of power that is transferred by the line. The economic voltage calculation results for the high-demand scenarios show that the standard economic voltage exceeded $275 \mathrm{kV}$ in 2029. The transmission line exceeding the standard is Wotu- Tentena, which requires a transmission voltage of $302.3 \mathrm{kV}$.

In the N-1 contingency criteria, the most congested line would be simulated. The simulation would show the system condition when the outage occurred. This N-1 contingency criterion is similar to the load flow, i.e., the voltage magnitude limit is between 0.95 and 1.05 p.u.; the maximum voltage angle difference is $30^{\circ}$, and only differs by the loading limit of $100 \%$. The simulation results show that at the voltage level of $275 \mathrm{kV}$ in 2034 for the high-demand scenario, the voltage magnitude limit was violated at Tentena Station, which was equal to 0.939 p.u. Meanwhile, the $500 \mathrm{kV}$ voltage level still met the requirements.

A voltage stability simulation was performed on the bus/station with the highest load in two conditions, namely the normal condition and N-1 contingency conditions. At the $275 \mathrm{kV}$ level voltage base-demand scenario, the voltage stability criterion was violated in 2037 in the Daya Baru Station; this violation occurred when a contingency occurred in the transmission line of Sidrap-Daya Baru. In the high-demand scenario, a violation occurred in the same place as the base demand, but the violation occurred in 2034. Meanwhile, for the $500 \mathrm{kV}$ voltage level, both the base demand and high-demand scenarios still met the voltage stability requirements.

\subsection{Economic Voltage}

Based on Equation (1), economic voltage is affected by two parameters, namely the length of the transmission line and the power transferred by the transmission line. The longer the transmission line, the greater the economic voltage; therefore, the greater the power transferred, the greater the economic voltage. Economic voltage calculation results are declared "safe" if they are smaller than the backbone voltage. The economic voltage 
limit was broken in 2029 at the $275 \mathrm{kV}$ backbone with the high-demand scenario, and the transmission line that exceeded the limit was Wotu-Tentena $2 \mathrm{a}$. The complete calculation results of the economic voltage on the Wotu-Tentena 2a lines are presented in Table 8.

Table 8. Economic voltage of Wotu-Tentena 2a in the $275 \mathrm{kV}$ backbone in the high-demand scenario.

\begin{tabular}{ccc}
\hline Year & Power Transferred (MW) & Economic Voltage (kV) \\
\hline 2024 & 82.03 & 136.09 \\
\hline 2026 & 317.93 & 257.08 \\
\hline 2029 & 443.37 & 302.30 \\
\hline 2031 & 219.14 & 214.87 \\
\hline 2034 & 406.77 & 289.84 \\
\hline
\end{tabular}

The length of the Wotu-Tentena 2a line is $104.5 \mathrm{~km}$, and there was no change in length during the transmission planning period. This means that the amount of power transferred affects the economic voltage value. Table 8 shows that the power transferred increased over time until 2029, when there was a limit break of the economic voltage. Meanwhile, in 2031, there was a decrease in the power transferred, such that the economic voltage remained safe; this happens because the power is transferred through another transmission line.

In fact, the violation of the economic voltage was not fatal, as although the economic voltage was violated, the load flow could still run normally. In order to avoid the violation of the economic voltage, the power transferred can be reduced by dividing it into other transmission lines, as occurred in 2031.

\subsection{N-1 Contingency}

In the $\mathrm{N}-1$ contingency condition, two parameters were evaluated, namely the voltage magnitude on each bus and the loading of each transmission line. The simulation results show that the N-1 contingency criteria were violated in 2034 when the Wotu-Tentena 1a line incurred a loss precisely at the $275 \mathrm{kV}$ backbone during high-demand scenarios. The details of the parameters that were evaluated in these conditions can be seen in Table 9 .

Table 9. N-1 contingency criteria in 2034 in a high-demand scenario.

\begin{tabular}{|c|c|c|c|c|c|}
\hline No. & Backbone Voltage & \multicolumn{2}{|c|}{ Voltage Magnitude (p.u.) } & \multicolumn{2}{|l|}{ Loading (\%) } \\
\hline \multirow{3}{*}{1} & \multirow{3}{*}{$275 \mathrm{kV}$} & Tentena & 0.939 & Wotu-Tentena 2_a & 49.36 \\
\hline & & Palu Baru & 0.957 & Daya Baru-Punagaya 275 kV & 19.52 \\
\hline & & Daya Baru & 0.954 & Wotu-PLTA Salu Uro 275 kV & 17.38 \\
\hline 2 & $500 \mathrm{kV}$ & All bus voltage & the standard & All line loading still fulfill & andard \\
\hline
\end{tabular}

The Wotu-Tentena transmission line that incurred a loss during the contingency had the largest loading compared to the other lines. This transmission line is also an important line because it connects the Northern Sulawesi subsystem and the Southern Sulawesi subsystem. The loss in the Wotu-Tentena 1a line will certainly affect the system, especially regarding components located close to the line. Based on Table 9, it is shown that the Tentena Station experienced an undervoltage of 0.939 p.u., whereas before the contingency, the Tentena Station voltage magnitude was 0.979 p.u. Meanwhile, other stations near the Wotu-Tentena 1a line also experienced a voltage drop, namely the Palu Baru Station, from 0.966 to 0.957 p.u. and the Daya Baru Station, from 0.967 to 0.954 p.u.

The voltage drop in the stations around the loss line occurred because the power that should pass through the line must be diverted through another line. As a result, the voltage drop in the other lines increased, such that the bus voltage decreased. In addition, the 
increase in the voltage drop also caused an increase in power losses in the transmission line.

In addition, the contingency also influenced the line loading. The Wotu-Tentena $2 \mathrm{a}$ line was the most affected; this line loading before the contingency was $24.47 \%$, and increased to $49.36 \%$ after the contingency. In addition, other lines also experienced a slight increase in loading due to the addition of power losses, as described previously.

\subsection{Voltage Stability}

The voltage stability on a bus was evaluated by considering the load connected to the bus and the point of critical power $\left(\mathrm{P}_{\text {crit }}\right) . \mathrm{P}_{\text {crit }}$ is the maximum power that can be handled by the bus; if the power exceeds $\mathrm{P}_{\text {crit }}$, then voltage collapse will occur. The $\mathrm{P}_{\text {crit }}$ value itself was obtained from voltage stability simulation using a continuation power flow; if the bus load exceeds $90 \%$ of the $\mathrm{P}_{\text {crit }}$ value, then the bus is unstable. The selected stations for the voltage stability simulation were those connected to the biggest load. Based on the simulation results, a voltage stability violation occurred in the $275 \mathrm{kV}$ backbone both in the base-demand and high-demand scenarios. Meanwhile, in the $500 \mathrm{kV}$ backbone, the voltage stability was still safe in both scenarios.

In the $275 \mathrm{kV}$ backbone in the base-demand scenario, the voltage stability was violated in the Daya Baru Station; details of the changes in the PV curve from 2031, 2034 and 2037 are shown in Figure 11. In 2031, the load connected to the Daya Baru Station was 1352 MW, and the $\mathrm{P}_{\text {crit }}$ result obtained by the simulation was $2133 \mathrm{MW}$. This shows that the voltage stability is still safe as the load is smaller than $90 \% \mathrm{P}_{\text {crit }}$. Furthermore, when a contingency occurred in the line of Daya Baru-Sidrap 2, the $\mathrm{P}_{\text {crit }}$ decreased to $1723 \mathrm{MW}$; this was still in accordance with the standard where the load was less than $90 \%$ Pcrit. The decrease in $\mathrm{P}_{\text {crit }}$ in this contingency is due to the bus becoming more vulnerable, meaning that a slight increase in power will cause a bigger voltage drop than normal.

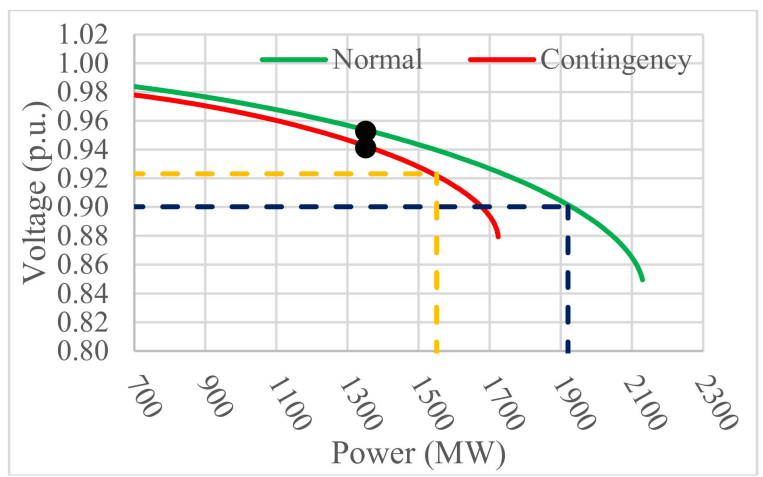

(a)

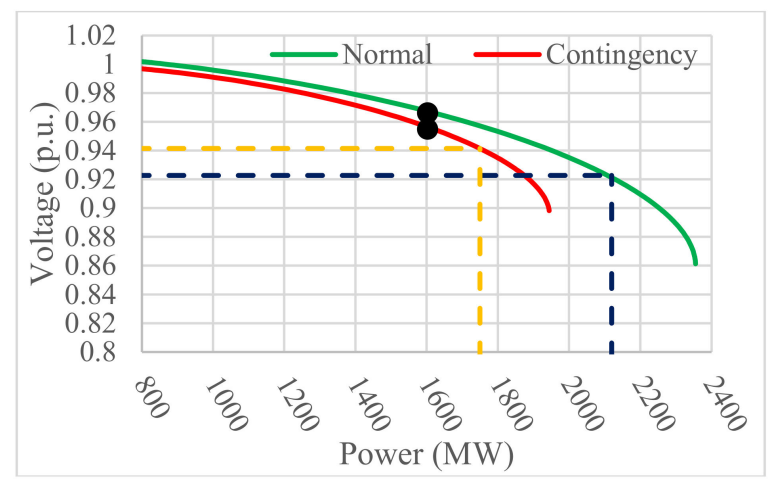

(b)

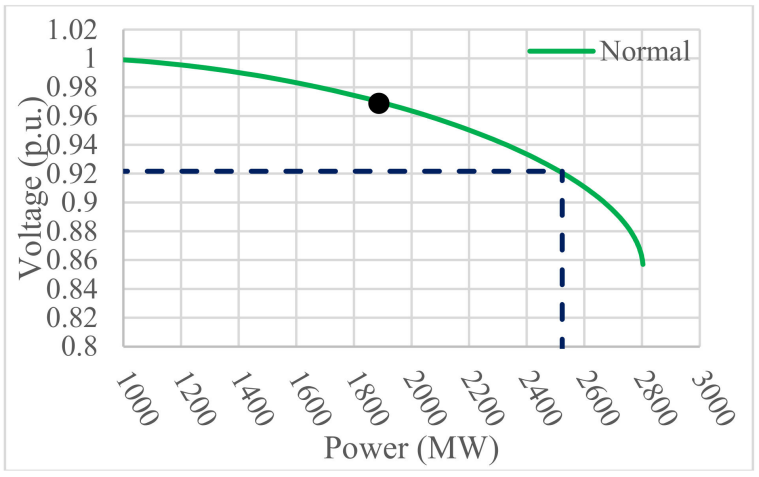

(c)

Figure 11. PV curve at Daya Baru Station for the $275 \mathrm{kV}$ backbone in the base-demand scenario: (a) 2031, (b) 2034, and (c) 2037. 
In 2034 and 2037, the load increased to 1603 and $1887 \mathrm{MW}$, respectively, while the $\mathrm{P}_{\text {crit }}$ became 2355 and $2803 \mathrm{MW}$. The increase in $\mathrm{P}_{\text {crit }}$ was not caused by the increase in the load, but due to the addition of generators enabling the system to become more robust. The increase in $\mathrm{P}_{\text {crit }}$ was smaller than the load growth, such that the margin between the load and $\mathrm{P}_{\text {crit }}$ was smaller, although it still met the standard. However, when there was a contingency in the line of Daya Baru-Sidrap 2, $\mathrm{P}_{\text {crit }}$ decreased to $1944 \mathrm{MW}$ in 2034, while in 2037 the voltage stability standard was violated, such that the curve could not be plotted (Figure 11c).

At $275 \mathrm{kV}$ in the high-demand scenario, the largest load was also located in the Daya Baru Station, with the PV curve as shown in Figure 12. In 2031, the load in the Daya Baru Station was $1488 \mathrm{MW}$ greater than that in the base-demand scenario; the $\mathrm{P}_{\text {crit }}$ value was also greater, that is, $2942 \mathrm{MW}$, and $2400 \mathrm{MW}$ when the contingency was in the line of Daya Baru-Sidrap 2. The $\mathrm{P}_{\text {crit }}$ value was higher because the high-demand scenario has more generators than the base-demand scenario. Then, in 2034, there was an increase in the load to $1801 \mathrm{MW}$ and a $\mathrm{P}_{\text {crit }}$ of $3288 \mathrm{MW}$; meanwhile, when the contingency occurred, the voltage stability was violated.

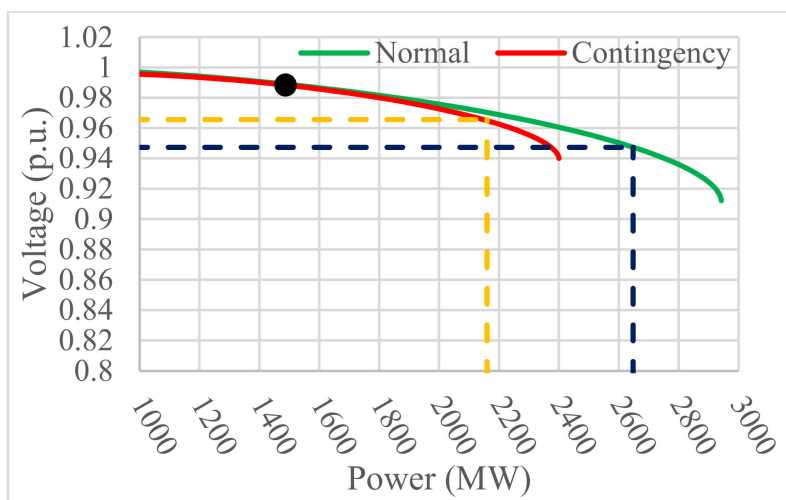

(a)

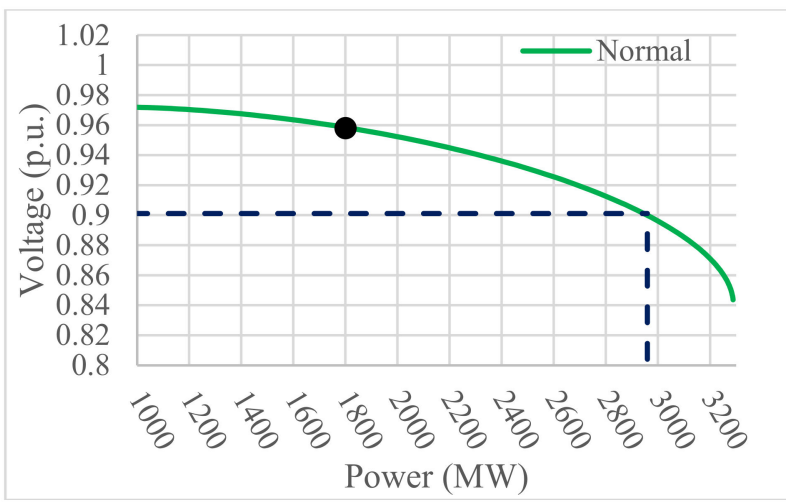

(b)

Figure 12. PV curve at Daya Baru Station for the $275 \mathrm{kV}$ backbone in the high-demand scenario: (a) 2031, (b) 2034.

For the $500 \mathrm{kV}$ backbone for both scenarios, all of the voltage stabilities remained at safe limits; this is due to the fact that at higher voltage levels, the system is more stable. When the load is the same, but the voltage is higher, the current will be smaller, so the voltage drop is smaller. The smaller the voltage drop, the greater the $\mathrm{P}_{\text {crit }}$ value. For comparison, Figure 13 shows the PV curve at the same time that $275 \mathrm{kV}$ was violated. In the base-demand scenario in 2037, the load at $500 \mathrm{kV}$ was equal to $275 \mathrm{kV}$, which is $1887 \mathrm{MW}$, but the $\mathrm{P}_{\text {crit }}$ value was greater at 4671 and $3762 \mathrm{MW}$ for the normal and contingency scenarios, respectively. Likewise, for the high-demand scenario in 2034, the load was the same, which was $1801 \mathrm{MW}$, but the $\mathrm{P}_{\text {crit }}$ values were greater, which were 3309 and 2695 MW for the normal and contingency scenarios, respectively. 


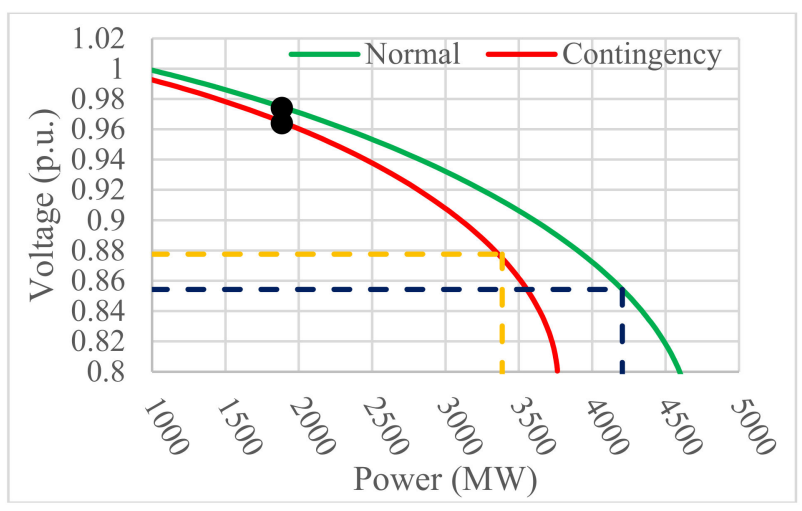

(a)

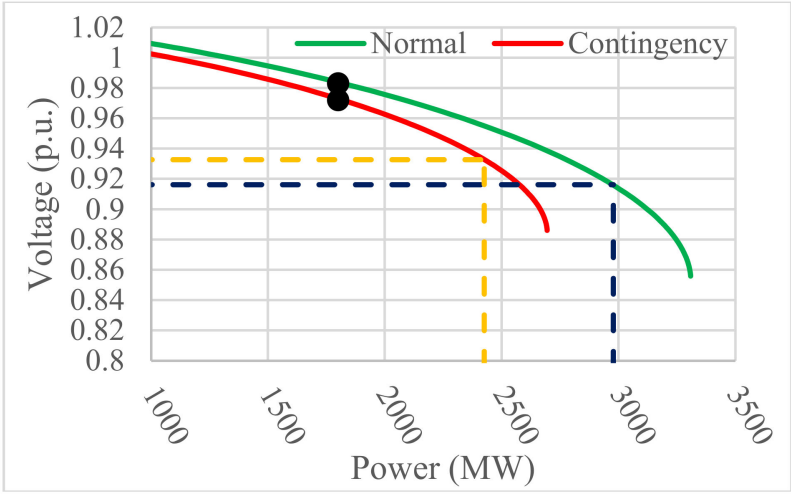

(b)

Figure 13. PV curve at Daya Baru Station for the 500 kV backbone: (a) 2037, base demand; (b) 2034, high demand.

\section{Conclusions}

Considering the power transfer from the renewable energy source to the load center, the transmission line adequacy, which consists of some criteria, should be considered. In Sulawesi Island, the locations of renewable energy resources are far from the load center. For example, the load center is located in Makassar city or exactly at Daya Baru Station, while the hydro energy resources are located around Bakaru Station in Pinrang District, which is $240 \mathrm{~km}$ away, and the wind energy resources are located in Sidrap, which is $175 \mathrm{~km}$ away. The selection of the backbone voltage levels was based on the technical criteria that must be fulfilled, including the economic voltage, voltage angle, $\mathrm{N}-1$ contingency, short circuiting, transient stability, voltage stability and small signal stability. Each of these criteria has certain standards, and the evaluation of each criterion was carried out within two scenarios, namely base demand and high demand, in order to consider the load forecast error in the future with two voltage options, 275 and $500 \mathrm{kV}$. The evaluation results allowed $500 \mathrm{kV}$ to be chosen as the transmission backbone voltage level, as it can meet all of the required standards during the planning period. However, $275 \mathrm{kV}$ does not meet the requirement due to the violation of three criteria, namely the economic voltage, $\mathrm{N}-1$ contingency and voltage stability. For example, in the high-demand scenario, the economic voltages of $275 \mathrm{kV}$ in 2029 and 2034 became 302.3 and $289.84 \mathrm{kV}$, respectively, which violates the safe requirement to be under the backbone voltage. Thus, in order to achieve the energy mix target, a transmission line upgrade to $500 \mathrm{kV}$ is required. The studies that were carried out can form the basis of the formulation of policies contained in the electricity supply business plan, such that RE utilization can be increased and mixed energy targets can be achieved. Furthermore, the same analysis could also be applied in systems where the location of the renewable energy power plant is far from the load center, such as the China and Finland systems.

Author Contributions: Conceptualization, T., L.M.P., R.I. and S.; methodology, L.M.P., R.I. and S.; software, L.M.P. and R.I.; validation, T., L.M.P., R.I., S., A.P., S.I. and I.S.; formal analysis, T., L.M.P. and S.; investigation, T., L.M.P. and S.; resources, L.M.P., S., A.P., S.I. and I.S.; data curation, T., L.M.P., S.I. and I.S.; writing — original draft preparation, T., L.M.P., R.I. and S.; writing-review and editing, L.M.P. and R.I.; visualization, L.M.P. and R.I.; supervision, T.; project administration, T. and L.M.P. All authors have read and agreed to the published version of the manuscript.

Funding: This research received no external funding.

Institutional Review Board Statement: Not applicable.

Informed Consent Statement: Not applicable.

Data Availability Statement: Not applicable. 
Acknowledgments: This work was performed with PT PLN (Persero) System Planning Division in 2018 under grant number 0707.PJ/DAN.02.06/DIV SIS/2017. All of the technical data was provided by our partner from PLN.

Conflicts of Interest: The authors declare no conflict of interest.

\section{References}

1. The World Bank. Total Population. 2019. Available online: https://data.worldbank.org/indicator/SP.POP.TOTL?locations=ID (accessed on 19 November 2020).

2. The World Bank. Population Growth (Annual\%). 2019. Available online: https://data.worldbank.org/indicator/SP.POP.GROW? locations $=$ ID (accessed on 19 November 2020).

3. Kementerian Kesehatan Republik Indonesia (Ministry of Health Republic of Indonesia). Profil Kesehatan Indonesia 2018 (Indonesia Health Statistic 2018); Kementerian Kesehatan Republik Indonesia (Ministry of Health Republic of Indonesia): Jakarta, Indonesia, 2019; ISBN 6221527716.

4. The World Bank. Getting Electricity-A Pilot Study by the Doing Business Project. Available online: https://www.doingbusiness. org/content/dam/doingBusiness / media/Special-Reports /Getting-Electricity-Pilot-Indicator-Project.pdf (accessed on 25 December 2020).

5. PT PLN (Persero) Statistik PLN 2018 (PLN Statistics 2018). Sekr. Perusah. PT PLN 2019, 53, 1689-1699. [CrossRef]

6. International Monetary Fund. World Economic Outlook; International Monetary Fund, Publication Services: Washington, DC, USA, 2019; ISBN 1557757402.

7. The World Bank. Electric Power Consumption (kWh per Capita)—Indonesia. 2019. Available online: https://data.worldbank. org/indicator/EG.USE.ELEC.KH.PC?locations=ID (accessed on 25 December 2020).

8. Kementrian Perindustrian Republik Indonesia (Ministry of Industry Republic of Indonesia). Rencana Induk Pembangunan Industri Nasional (National Industry Development Master Plan); Kementrian Perindustrian Republik Indonesia (Ministry of Industry Republic of Indonesia): Jakarta, Indonesia, 2015.

9. Kementrian Perindustrian Republik Indonesia (Ministry of Industry Republic of Indonesia). Facts and Figures 2017; Kementrian Perindustrian Republik Indonesia (Ministry of Industry Republic of Indonesia): Jakarta, Indonesia, 2017.

10. Kementerian Energi dan Sumber Daya Mineral Republik Indonesia (Ministry of Energy and Mineral Resources Republic of Indonesia). Rencana Usaha Penyediaan Tenaga Listrik PT. PLN (Persero) 2019-2028 (Electricity Supply Business Plan); Kementerian Energi dan Sumber Daya Mineral Republik Indonesia (Ministry of Energy and Mineral Resources Republic of Indonesia): Jakarta, Indonesia, 2019.

11. Amado, N.B.; Del, E.; Pelegia, B. Capacity Value from Wind and Solar Sources in Systems with Variable Dispatchable CapacityAn Application in the Brazilian Hydrothermal System. Energies 2021, 14, 3196. [CrossRef]

12. Dunkelberg, H.; Sondermann, M.; Meschede, H.; Hesselbach, J. Assessment of flexibilisation potential by changing energy sources using Monte Carlo simulation. Energies 2019, 12, 711. [CrossRef]

13. Dehdarian, A.; Tucci, C.L. A complex network approach for analyzing early evolution of smart grid innovations in Europe. Appl. Energy 2021, 298, 117143. [CrossRef]

14. Witt, T.; Klumpp, M. Multi-Period Multi-Criteria Decision Making under Uncertainty: A Renewable Energy Transition Case from Germany. Sustainability 2021, 13, 6300. [CrossRef]

15. Ali, E.S.; El-Sehiemy, R.A.; Abou El-Ela, A.A.; Mahmoud, K.; Lehtonen, M.; Darwish, M.M.F. An effective Bi-stage method for renewable energy sources integration into unbalanced distribution systems considering uncertainty. Processes 2021, 9, 471. [CrossRef]

16. UNFCCC. Indonesia: First Nationally Determined Contribution; United Nations Climate Change: Bonn, Germany, 2016 ; p. 18.

17. Kementerian Energi dan Sumber Daya Mineral Republik Indonesia (Ministry of Energy and Mineral Resources Republic of Indonesia). Rencana Usaha Penyediaan Tenaga Listrik PT. PLN (Persero) 2018-2027 (Electricity Supply Business Plan); Kementerian Energi dan Sumber Daya Mineral Republik Indonesia (Ministry of Energy and Mineral Resources Republic of Indonesia): Jakarta, Indonesia, 2018.

18. Pusat Kajian LKFT Universitas Gadjah Mada (LKFT Study Center Universitas Gadjah Mada). Penyusunan Kajian Masterplan Kelistrikan Sulawesi (The Sulawesi Electricity Master Plan Study); Pusat Kajian LKFT Universitas Gadjah Mada (LKFT Study Center Universitas Gadjah Mada): Yogyakarta, Indonesia, 2018.

19. Zhang, X.; Conejo, A.J. Candidate line selection for transmission expansion planning considering long- and short-term uncertainty. Int. J. Electr. Power Energy Syst. 2018, 100, 320-330. [CrossRef]

20. Guerra, O.J.; Tejada, D.A.; Reklaitis, G.V. An optimization framework for the integrated planning of generation and transmission expansion in interconnected power systems. Appl. Energy 2016, 170, 1-21. [CrossRef]

21. Gomes, P.V.; Saraiva, J.T. State-of-the-art of transmission expansion planning: A survey from restructuring to renewable and distributed electricity markets. Int. J. Electr. Power Energy Syst. 2019, 111, 411-424. [CrossRef]

22. Liang, Z.; Chen, H.; Chen, S.; Lin, Z.; Kang, C. Probability-driven transmission expansion planning with high-penetration renewable power generation: A case study in northwestern China. Appl. Energy 2019, 255, 113610. [CrossRef]

23. Wu, Z.; Liu, Y.; Gu, W.; Wang, Y.; Chen, C. Contingency-constrained robust transmission expansion planning under uncertainty. Int. J. Electr. Power Energy Syst. 2018, 101, 331-338. [CrossRef] 
24. Yi, B.W.; Xu, J.H.; Fan, Y. Inter-regional power grid planning up to 2030 in China considering renewable energy development and regional pollutant control: A multi-region bottom-up optimization model. Appl. Energy 2016, 184, 641-658. [CrossRef]

25. Lumbreras, S.; Ramos, A.; Banez-Chicharro, F. Optimal transmission network expansion planning in real-sized power systems with high renewable penetration. Electr. Power Syst. Res. 2017, 149, 76-88. [CrossRef]

26. Roldán, C.; García-Bertrand, R.; Mínguez, R. Robust transmission expansion planning with uncertain generations and loads using full probabilistic information. Electr. Power Syst. Res. 2020, 189, 106793. [CrossRef]

27. Taherkhani, M.; Hosseini, S.H.; Javadi, M.S.; Catalão, J.P.S. Scenario-based probabilistic multi-stage optimization for transmission expansion planning incorporating wind generation integration. Electr. Power Syst. Res. 2020, 189, 106601. [CrossRef]

28. Das, S.; Verma, A.; Bijwe, P.R. Security constrained AC transmission network expansion planning. Electr. Power Syst. Res. 2019, 172, 277-289. [CrossRef]

29. Abbasi, S.; Abdi, H.; Bruno, S.; La Scala, M. Transmission network expansion planning considering load correlation using unscented transformation. Int. J. Electr. Power Energy Syst. 2018, 103, 12-20. [CrossRef]

30. Mehta, V.K. Text Book of Principal of Power System; S. Chand \& Co. Ltd.: New Delhi, India, 2005; pp. 461-462.

31. Greingnger, D.W.; Jhon, J. Power System Analysis; McGraw-Hill, Inc.: New York, NY, USA, 1994.

32. Saadat, H. Power System Analysis, 2nd ed.; McGraw-Hill, Inc.: New York, NY, USA, 1999.

33. Kundur, P. Power System Stability and Control; McGraw-Hill, Inc.: New York, NY, USA, 1994; Volume III, ISBN 9781439883211.

34. Nise, N.S. Control System Engineering, 7th ed.; John Wiley and Sons Inc.: Hoboken, NJ, USA, 2014; ISBN 978-1118170519.

35. PowerFactory DIgSILENT. Technical Reference Documentation-Synchronous Machine; DIgSILENT GmbH: Gomaringen, Germany, 2015; Volume 1, pp. 1-40. [CrossRef]

36. Japan International Cooperation Agency Nippon Koei, Co. Project for the Master Plan Study of Hydropower Development in Indonesia; The Republic of Indonesia Ministry of Energy and Mineral Resources: Jakarta, Indonesia, 2011; Volume II. 